\title{
АГРОЕКОЛОГІЧНІ ОСНОВИ ВИРОЩУВАННЯ ЕКОЛОГІЧНО БЕЗПЕЧНОЇ ТОВАРНОЇ ПРОДУКЦІЇ М'ЯТИ ПЕРЦЕВОЇ
}

\author{
О.В. Василенко \\ кандидат сільськогосподарської наук, доцент \\ Уманський національний університет садівництва \\ (Україна, м. Умань; e-mail: vsolga05@gmail.com) \\ А.В. Балабак \\ кандидат сільськогосподарської наук, доцент \\ Уманський національний університет садівництва \\ (Україна, м. Умань; e-mail: A.V.Balabak@ukr.net)
}

Проведено трирічні дослідження впливу мікробіологічних препаратів на врожайність та якість товарної продукиї м’яти перцевої. Предметом дослідження були фенологічні зміни, біометричні показники та параметри врожайності рослин залежно від внесення мікробіологічних препаратів, як-от: ЕM-А, Сяйво-2 та ЕM-пластини. Під час проведення наукової роботи були використані польовий, статистичний, лабораторний методи дослідженъ. Здійснено фбенологічні спостереження, біометричні вимірювання, обліки та біохімічний аналіз рослин. Обгрунтовано закономірності борлування високого рівня врожайності товарної продукиї м'яти периевої залежно від застосування ЕM-препаратів. Встановлено, шуо підживлення рослин м'яти периевої впродовж вегетації розчином мікробіологічного препарату ЕМ-А стимулювало наростання листової маси і поліпшувало облиствленість рослин, а отже $і$ врожайність культури у иъому варіанті досліду була найвищою - 3,9 m/га. Доведено, шо за дї̈ всіх використаних у досліді мікробіологічних препаратів уміст нітратів у зеленій масі м’яти периевої знижувався порівняно із контролем. Крім того, нашими дослідженнями виявлено тенденцію до збільшення вмісту ебірної олї̈ в листках м’яти периевої під дією мікробіологічних препаратів. Доведено позитивний вплив мікробіологічних препаратів на ріст, розвиток та врожайність кулътури та визначено, шо застосування мікробіологічного препарату ЕМ-А під час вегетаиїі рослин є ебективним, екологічно безпечним елементом сучасної технологї вирощування культури.

Ключові слова: м’ята перцеева, мікробіологічні препарати, EM-A, Сяйво-2, EM-пластини, підживлення, врожайність, нітрати, ебірна олія, товарна продукиія.

Постановка проблеми. В основу екологічно безпечного сільського господарства покладено п'ять принципів, як-от: виробництво екологічно чистої сільськогосподарської продукції, здатної покращувати здоров'я людей; економічна перевага для виробників і споживачів; надійність і доступність для відтворення; збереження довкілля; виробництво необхідної кількості високоякісної продукції (з урахуванням дедалі зростаючих потреб населення) [1].

За традиційного землеробства в грунті після збору врожаю поживних речовин залишається тільки для росту бур'янів. А щоб отримати добрий урожай культурних рослин, за правилами агрохімії необхідно вносити синтетичні мінеральні добрива у кількості, аби повністю компенсувати внесені з грунту поживні речовини. Так, єдиним джерелом живлення за традиційної системи землеробства є застосування мінеральних добрив [2;3].

Використання еоективних мікроорганізмів (EM) у практиці органічного землеробства запропонував доктор Теруо Хига, профресор університету з Окінави (Японія) у 80-х рр. XX ст. [4]. Він розробив концепцію введення мікроорганізмів у грунти і безпосередньо у рослини з метою створення сприятливішого мікробіологічного довкілля для зростання рослин. Згідно з цією концепцією була культивована група корисних мікроорганізмів, які надалі використовувалися як засіб для поліпшення стану грунту, пригнічення збудників хвороб, що викликаються мікроорганізмами, і підвищення ефективності використання живильних речовин сільськогосподарськими культурами $[5,6]$.

Аналіз останніх досліджень і публікацій. Головне завдання EM-технології - це отримання високоякісних смакових і лікувальних продуктів харчування для людей. Так, EMтехнологія дає можливість очистити грунт від хімічних речовин та повернути із «мертвого» стану в біологічно активний, що забезпечує високий рівень його родючості [7; 8; 9]. 
Завдяки EM-технології рослини отримують своєрідний живий захисний щит від хвороб і шкідників. Рівень майбутньої врожайності, як і стійкість рослин до хвороб, залежить від якості посівного матеріалу [10]. Продукція, вироблена за EM-технологією, краще зберігається, ніж вирощена традиційним способом [11; 12].

Дослідження впливу мікробіологічних препаратів на поживний режим грунтів викладено у працях М.M. Городнього [13] та А.С. Кузьменка [14] і В.В. Волкогона [15]. Ці вчені дійшли висновку, що застосування мікробіологічних препаратів мобілізує доступні рослинам фоссрати грунту. Крім того, ці препарати можуть не лише підвищувати стійкість рослин до хвороб і стресів, але і підвищувати ix врожайність, покращувати якість продукціі та збільшувати економічний ефект від вирощування.

Виділення невирішених раніше частин загальної проблеми. На сьогодні немає науково обгрунтованих технологій вирощування м'яти перцевої з використанням EM-препаратів у будь-яких грунтово-кліматичних зонах України. Тому вивчення цих технологічних засобів для отримання екологічно безпечної продукції та розробка рекомендацій для впровадження результатів досліджень у виробництво є доволі актуальним питанням.

Метою дослідження є вивчення агроекологічних прийомів технології вирощування товарної продукції м'яти перцевої з використанням EM-препаратів та визначення їх впливу на якість товарної продукції.

Матеріали та методи. Дослідження проводили впродовж 2016-2018 рр. з використанням мікробіологічних препаратів EM-A, Сяйво-2 та EM-пластин в умовах польового досліду.
Перцеву м'яту розмножували вегетативно (поділом кореневища). Свіжі непророслі кореневища висаджували вручну квадратно-гніздовим $(45 \times 45$ см) способом у другій декаді квітня.

Рослини обприскували через 10 днів після висаджування кореневищ (перший рік вегетаціі) або після відновлення вегетації у наступні роки, а потім упродовж вегетації через кожні 7 днів. EM-пластини розміщували вертикально, злегка заглибивши у грунт на відстані 20 см від рослини, відразу після висаджування кореневищ. За контроль було прийнято варіант вирощування рослин без обробки мікробіологічними препаратами.

У науковій роботі були використані польовий, статистичний, лабораторний методи досліджень. Здійснювали фенологічні спостереження, біометричні вимірювання, обліки та біохімічний аналіз рослин.

Викладення основного матеріалу. Впродовж вегетаційного періоду проводили біометричні вимірювання, що надало змогу проаналізувати динаміку наростання вегетативної маси лікарської сировини м'яти перцевої впродовж трьох років. Щорічно визначали кількість рослин, які добре перезимували, на основі чого встановили, що у першій декаді квітня 98-100\% рослин відновлювали вегетацію, а це свідчить про повну адаптацію рослини до природних умов зони досліджень.

Аналіз отриманих результатів засвідчив, що рослини різного віку значно відрізняються своїм габітусом, насамперед висотою, залежно від внесення мікробіологічних препаратів (табл. 1). Вимірювали біометричні параметри рослин чотири рази за вегетаційний період, тобто було простежено динаміку росту всього куща м'яти перцевої.

таблиия 1

Висота рослин м'яти перцевої залежно від застосування мікробіологічних препаратів, см

\begin{tabular}{|l|c|c|c|c|}
\hline \multirow{2}{*}{ Обробка мікробіологічними препаратами } & \multicolumn{3}{|c|}{ Роки досліджень } & \multirow{2}{*}{ Середне за 2016-2018 pp. } \\
\cline { 2 - 5 } & $\mathbf{2 0 1 6}$ & $\mathbf{2 0 1 7}$ & $\mathbf{2 0 1 8}$ & \\
\hline \hline \multicolumn{7}{|c|}{ Фаза початку бутонізацїі } \\
\hline без обробки (контроль) & 39,8 & 41,2 & 38,7 & 39,9 \\
\hline обприскування розчином ЕМ-А & 43,9 & 44,1 & 43,4 & 43,8 \\
\hline обприскування препаратом Сяйво-2 & 43,4 & 43,9 & 42,9 & 43,4 \\
\hline використання ЕМ-пластини & 42,9 & 42,1 & 41,3 & 42,1 \\
\hline \multicolumn{7}{|c|}{ Фаза повного иявітіння } \\
\hline без обробки (контроль) & 122,9 & 123,4 & 122,4 & 122,9 \\
\hline обприскування розчином ЕМ-А & 136,9 & 137,6 & 136,2 & 136,9 \\
\hline обприскування препаратом Сяйво-2 & 133,4 & 134,3 & 133,1 & 133,6 \\
\hline використання ЕМ-пластини & 128,3 & 127,8 & 127,6 & 127,9 \\
\hline
\end{tabular}


За роки досліджень рослини м'яти перцевої різнилися за висотою. Так, вищі і, відповідно, краще розвинені рослини сорормувались впродовж вегетації 2017 р. Це можна пояснити сприятливими погодними умовами вегетації, а також тим, що це був другий рік вегетації рослини на одному місці.

Якщо проаналізувати вплив на висоту рослини різних мікробіологічних препаратів, то можна зробити висновок, що оптимальним варіантом підживлення у досліді є обробка рослин розчином ЕM-А. У фразі початку цвітіння в середньому за роки досліджень висота рослин у цьому варіанті становила 74,0 см. Це вище за показник контрольного варіанта на 3,9 см.

Періодична обробка рослин розчинами препаратів EM-A та Сяйво-2 також мали позитивний вплив на висоту рослини у фазі повного цвітіння, тобто перед збиранням зеленої маси. Порівняння показників вказаних варіантів досліду із контролем продемонструвало перевищення значень останнього на 10,7-14,0 cм (середнє за роки досліджень).

Також слід зауважити, що рослини другого року вегетації відрізнялись більшою висотою порівняно з рослинами першого року; щодо рослин третього року вегетації, то вони були нижчими внаслідок малої кількості опадів у другу половину вегетаційного періоду року.

Варіант застосування EM-пластин під час садіння кореневищ продемонстрував позитивні результати, особливо в перший рік після висаджування, а надалі рослини майже не відрізнялися висотою від рослин контрольного варіанта.
Збільшення висоти рослини та підвищення інтенсивності галуження сприяло збільшенню площі форосинтетичної поверхні (табл. 2).

Площа фотосинтетичної поверхні рослин м'яти перцевої — це показник основної її продуктивності, оскільки саме зелена маса рослини і є їі товарним продуктом. За результатами трирічних досліджень найбільшу площу фотосинтетичної поверхні рослини мали у фазу початку цвітіння, саме перед збиранням зеленої маси.

Найвищою площею фотосинтетичної поверхні відзначились рослини, які були підживлені розчином препарату EM-А впродовж всієї вегетації, що зумовлено інтенсивнішим галуженням та утворенням більшої кількості листків. У таких рослин площа одного пагона становила $241 \mathrm{~cm}^{2}$, а всього куща - $13382 \mathrm{~cm}^{2}$, що більше за показник контрольного варіан-

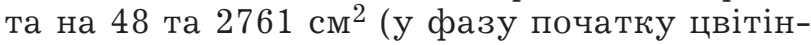
ня) відповідно. Це засвідчує, що підживлення мікробіологічними препаратами позитивно вплинуло на розвиток підземної багаторічної частини рослини i, відповідно, на наступний вегетаційний період забезпечило кращі умови іх живлення.

Накопичення цінних ефрірних олій перцевої м'яти активніше відбувається у листках та суцвіттях і залежить від динаміки наростання асиміляційної поверхні листків та загальної площі фотосинтетичної поверхні всієї рослини. Найвищих значень площа фотосинтетичної поверхні одного пагона досягла у фразі початку цвітіння. У фразу повного цвітіння спостерігалося зменшення фотосинтетичної поверхні одного

Таблицяя 2

Площа фотосинтетичної поверхні рослин м'яти перцевої залежно від застосування мікробіологічних препаратів, см² (середнс за 2016-2018 рр.)

\begin{tabular}{|c|c|c|}
\hline \multirow{2}{*}{ Обробка мікробіологічними препаратами } & \multicolumn{2}{|c|}{ Площа фотосинтетичної поверхні, см² } \\
\hline & одного пагона & всієї рослини \\
\hline \multicolumn{3}{|c|}{ Фаза початку бутонізаиї } \\
\hline без обробки (контроль) & 118 & 354 \\
\hline обприскування розчином EM-A & 129 & 392 \\
\hline обприскування препаратом Сяйво-2 & 126 & 378 \\
\hline використання EM-пластини & 120 & 361 \\
\hline \multicolumn{3}{|c|}{ Фаза початку ијвітіння } \\
\hline без обробки (контроль) & 193 & 10621 \\
\hline обприскування розчином EM-А & 241 & 13382 \\
\hline обприскування препаратом Сяйво-2 & 223 & 12564 \\
\hline використання EM-пластини & 197 & 11249 \\
\hline
\end{tabular}




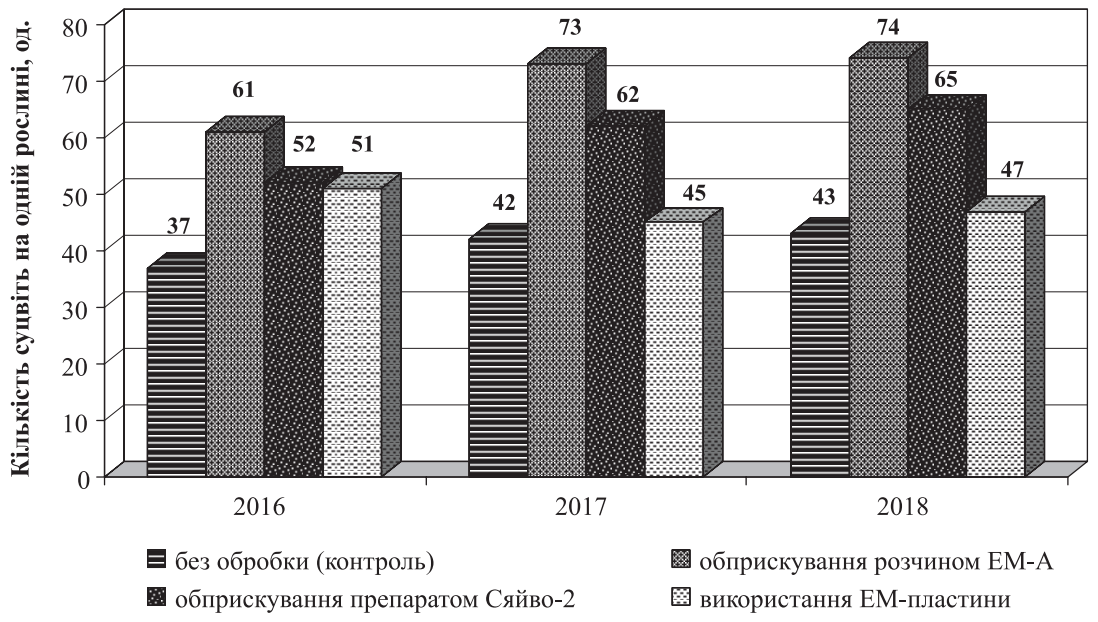

Рис. 1. Динаміка зміни кількості суцьвіть м’яти перцевої залежно від віку рослин та застосування мікробіологічних препаратів

пагона у всіх варіантах, що зумовлено заміною великих прикореневих листків на дрібніші у верхніх ярусах.

Найвища частка ефірних олій накопичується в суцвіттях м'яти перцевої, тому важливою характеристикою є їх кількість на одній рослині (рис. 1).

Найеоективнішим виявився варіант із підживленням рослин розчином препарату EM-A — кількість суцвіть за цих умов була більша, ніж у всіх інших варіантах досліду - різниця 3 показником контрольного варіанта становила 28,6 од. (середнє за роки досліджень).

Основна кількість суцвіть (близько 85\%) утворювалась на гілочках другого-третього порядків. 3 віком кількість продуктивних стебел на одну рослину збільшувала, особливо це можна відзначити на рослинах третього року.

Важливим показником ефективності вирощування і впровадження у виробництво нових технологічних прийомів (внесення мікро- біологічних препаратів) є рівень врожайності. Аналіз показників урожайності рослин за роками досліджень свідчить, що 2017 р. був найсприятливішим для вирощування м'яти перцевої, завдяки значній кількості опадів упродовж вегетаційного періоду (табл. 3).

В умовах нестачі вологи в грунті й пониженої вологості повітря (2016 та 2018 рр.), навіть незначне збільшення листкової поверхні, основного органа транспірації рослин, зумовлювало посилену втрату вологи, що несприятливо вплинуло на інтенсивність метаболізму і зрештою не могло не позначитись на зниженні продуктивності рослин. Про це свідчить нижча урожайність (2,8 т /га) підв' ялених до рівня $55 \%$ вологості рослин на ділянках контролю.

Підживлення рослин м'яти перцевої впродовж вегетації розчином препарату EM-A стимулювало наростання листової маси і поліпшувало облиствленість рослин. Відповідно і врожайність рослин у цьому варіанті досліду

Таблиияя 3

Вплив внесення мікробіологічних препаратів на врожайність надземної маси рослин сорту м'яти перцевої, т/га

\begin{tabular}{|c|c|c|c|c|c|c|}
\hline \multirow{2}{*}{$\begin{array}{c}\text { Обробка мікробіологічними } \\
\text { препаратами }\end{array}$} & \multicolumn{3}{|c|}{ Роки досліджень } & \multirow{2}{*}{$\begin{array}{c}\text { Середнє } \\
\text { за 2016-2018 рр. }\end{array}$} & \multicolumn{2}{|c|}{ 土 до контролю } \\
\hline & 2016 & 2017 & 2018 & & $\mathbf{T} / \mathbf{r a}$ & $\%$ \\
\hline Без обробки (контроль) & 2,7 & 3,1 & 2,6 & 2,8 & - & - \\
\hline $\begin{array}{l}\text { Обприскування розчином } \\
\text { EM-A }\end{array}$ & 3,8 & 4,1 & 3,8 & 3,9 & $+1,1$ & $+39,3$ \\
\hline $\begin{array}{l}\text { Обприскування препаратом } \\
\text { Сяйво-2 }\end{array}$ & 3,4 & 3,9 & 3,8 & 3,7 & $+0,9$ & $+32,1$ \\
\hline Використання EM-пластини & 3,4 & 3,8 & 3,3 & 3,5 & $+0,7$ & $+25,0$ \\
\hline $\mathrm{HIP}_{05}$ & 0,07 & 0,08 & 0,08 & & & \\
\hline
\end{tabular}


була найвищою - 3,9 т /га, що більше за показник контрольного варіанта на 1,1 т/га (39,3\%).

У варіантах із підживленням препаратом Сяйво-2 та з використанням ЕM-пластин також спостерігалися позитивні результати, хоч показники врожайності оброблених рослин були нижчими порівняно з попереднім варіантом.

Застосування ЕM-пластин істотно збільшило врожайність зеленої маси рослин - у середньому за роки досліджень цей показник становив 3,5 порівняно з 2,8 т/га у контрольному варіанті. Але, як свідчать результати дослідження, врожайність рослин у цьому варіанті була нижчою, ніж відповідний показник у інших варіантах із застосуванням мікробіологічних препаратів.

Слід наголосити на встановленій тенденції до збільшення вмісту ефірної олії в листках м'яти перцевої під дією мікробіологічних препаратів (табл. 4).

Якщо зважати на те, що окрім стимулювання росту рослин мікробіологічні препарати мають здатність активувати процес фротосинтезу і транспірації води листям, то посилення витрат вологи рослинами м'яти під час вегетації у разі нестачі вологи в грунті і повітрі не могло не позначитися на водному статусі рослин м'яти, a, відповідно, і на нагромадженні ефрірної олії в тканинах листків. Чим інтенсивніше відбуваються обмінні процеси в рослинному організмі, тим більше він чутливий до впливу чинників навколишнього природного середовища. Аналіз отриманих даних підтвердив цю закономірність.

За обробки рослин м'яти перцевої вказаними препаратами впродовж років досліджень, коли забезпеченість вологою була найнижчою, спостерігався менший уміст ефрірної олії у рослинах, незалежно від застосування мікробіологічних препаратів.

Це дає підстави стверджувати, що серед комплексу агрометеорологічних чинників у період вегетації, які істотно впливають на еоективність застосування мікробіологічних препаратів на посадках м'яти перцевої, вирішальним є забезпеченість рослин вологою, за нестачі якої різко гальмується як ріст рослин, так і реакція ї на обробку цим препаратом, унаслідок чого й ефективність застосування мікробіологічних препаратів як засобу підвищення збору ефрірної олії м'яти перцевої в посушливих умовах знижується (табл. 5).

Застосування мікробіологічного препарату EM-А у вигляді розчину шляхом прикоре-

Таблиияя 4

Вплив застосування мікробіологічних препаратів на нагромадження ефрірної олії в листі рослин м'яти перцевої, \%

\begin{tabular}{|c|c|c|c|c|c|}
\hline \multirow{2}{*}{$\begin{array}{c}\text { Обробка мікробіологічними } \\
\text { препаратами }\end{array}$} & \multicolumn{3}{|c|}{ Роки досліджень } & \multirow{2}{*}{$\begin{array}{c}\text { Середнє } \\
\text { за 2016-2018 pp. }\end{array}$} & \multirow{2}{*}{$\begin{array}{c} \pm \text { до } \\
\text { контролю }\end{array}$} \\
\hline & 2016 & 2017 & 2018 & & \\
\hline Без обробки (контроль) & 3,45 & 4,10 & 3,82 & 3,79 & - \\
\hline Обприскування розчином EM-A & 3,72 & 4,59 & 4,02 & 4,11 & $+0,32$ \\
\hline $\begin{array}{l}\text { Обприскування препаратом } \\
\text { Сяйво-2 }\end{array}$ & 3,61 & 4,48 & 4,09 & 4,06 & $+0,27$ \\
\hline Використання EM-пластини & 3,54 & 4,42 & 4,04 & 4,00 & $+0,21$ \\
\hline
\end{tabular}

Таблиияя 5

Вплив застосування мікробіологічних препаратів на олійну продуктивність м'яти перцевої, кг/га

\begin{tabular}{|c|c|c|c|c|c|}
\hline \multirow{2}{*}{$\begin{array}{c}\text { Обробка мікробіологічними } \\
\text { препаратами }\end{array}$} & \multicolumn{3}{|c|}{ Роки досліджень } & \multirow{2}{*}{$\begin{array}{c}\text { Середнє } \\
\text { за 2016-2018 pp. }\end{array}$} & \multirow{2}{*}{$\begin{array}{c} \pm \text { до } \\
\text { контролю }\end{array}$} \\
\hline & 2016 & 2017 & 2018 & & \\
\hline Без обробки (контроль) & 29,1 & 35,3 & 32,2 & 32,2 & - \\
\hline Обприскування розчином EM-A & 37,0 & 41,7 & 39,5 & 39,4 & $+7,2$ \\
\hline $\begin{array}{l}\text { Обприскування препаратом } \\
\text { Сяйво-2 }\end{array}$ & 36,9 & 40,8 & 39,0 & 38,9 & $+6,7$ \\
\hline Використання ЕM-пластини & 35,6 & 39,3 & 37,6 & 37,5 & $+5,3$ \\
\hline $\mathrm{HIP}_{05}$ & 0,3 & 0,4 & 0,1 & - & \\
\hline
\end{tabular}




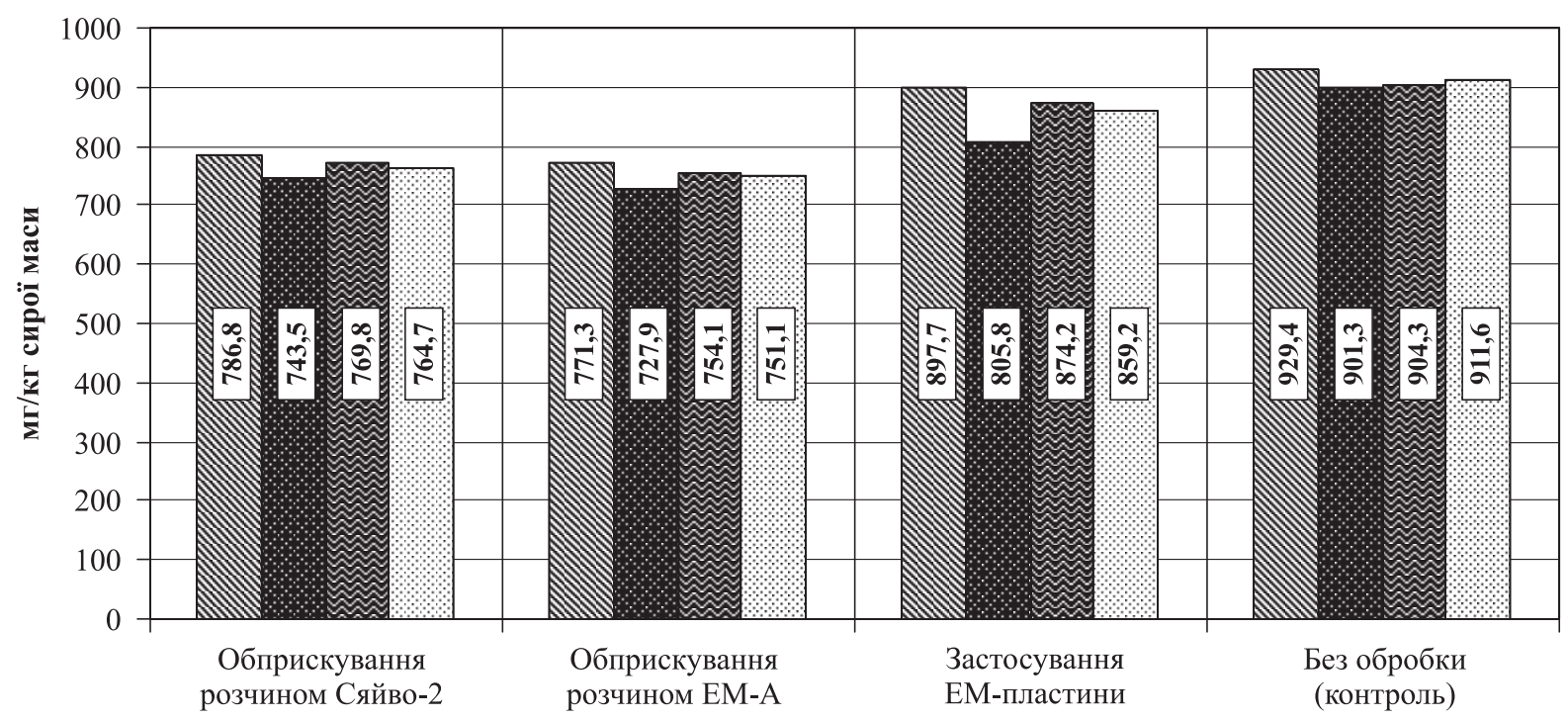

$$
2016 \text { p. } 2017 \text { p. } 2018 \text { p. } \text {. Середне за 2016-2018 pp. }
$$

Рис. 2. Уміст нітратів у зеленій масі м’яти периевої залежно від застосування мікробіологічних препаратів (ГДК - 1500 мг/кг)

невого підживлення рослин на посадках м'яти перцевої істотно збільшує виробництво ефрірної олії. Збір ефірної олії з рослин у цьому варіанті досліду становив $39,4 \mathrm{\kappa r} /$ га, що переважає показник контрольного варіанта на 7,2 кг/га, або на $22,4 \%$.

Встановлено, що застосування природних стимуляторів росту рослин, якими є препарати ефективних мікроорганізмів, забезпечує одержання екологічно безпечного врожаю м'яти перцевої, який характеризується високими показниками якості (рис. 2).

Отримані у досліді результати засвідчують, що за дії мікробіологічних препаратів, незалежно від іх вибору, вміст нітратів у зеленій масі м'яти перцевої знижувався порівняно із контролем.

Висновки. Рослини впродовж усіх етапів органогенезу за застосування досліджуваних мікробіологічних препаратів мали різні біометричні параметри (висоту, ступінь галуження та площу фотосинтетичної поверхні). Найбільші значення показників висоти рослини, ступеню галуження та загальної фотосинтетичної поверхні зафіксовано у варіанті із підживленням рослин розчином препарату EM-A.
Також за обробки рослин цим препаратом спостерігалася більша кількість суцвіть у рослин - різниця з показником контрольного варіанта становила 32 од., залежно від року проведення досліджень. Основна кількість суцвіть (близько 85\%) утворювалась на гілочках другого-третього порядків. 3 віком кількість продуктивних стебел на одну рослину збільшувалась.

Підживлення рослин м'яти перцевої впродовж вегетації розчином мікробіологічного препарату EM-А стимулювало наростання листової маси і поліпшувало облиствленість рослин. Відповідно і врожайність рослин у цьому варіанті досліду була найвищою - 3,9 т/га, що більше за такий самий показник контрольного варіанта на 1,1 т/га $(39,3 \%)$.

Також встановлено тенденцію до збільшення вмісту ефірної олії в листках м'яти перцевої під дією мікробіологічних препаратів. Застосування досліджуваних препаратів для підживлення рослин на посадках м'яти перцевої істотно збільшує виробництво ефрірної олії, тому може бути впроваджено в практику включеним як ефективний елемент сучасної технології вирощування цієї культури.

\section{СПИСОК ВИКОРИСТАНИХ ДЖЕРЕЛ}

1. Дубинский Г.П., Бураков В.И. Почвозащитное устройство агроландшафта. Харків: Вища школа, 2012. 216 с.

2. Паламарчук I. П., Паламарчук I. I. , Янович В. П. Технологічні аспекти використання ефективних мікроорганізмів у відновлюючи процесах. Збірник наукових праць Вінницького національного аграрного університету. № 10. Т. 1 (58). 2013. С. 164-167. 
3. Гутинська Г.О. Грунтова мікробіологія: Навчальний посібник Київ: Арістей, 2006. 284 с.

4. Тибурський І.Ю. Екологічне сільське господарство: кроки назустріч. Крок перший: екологічне землеробство: Посібник. Київ: Видавництво Національного аграрного університету, 2006. 80 с.

5. Стецишин П.О. , Пиндус В.В., Рекуненко В.В. та ін. Основи органічного виробництва: навч. посіб. для студ. агр. вищ. навч. закл. Вид. 2-ге, змін. і доповн. Вінниця: Нова книга, 2011. 626 с.

6. Зелінський М. Органічне землеробство - це шанс не виживати, а жити і розвиватись. Агросвіт України. 2015. № 1. С. 8-10.

7. Бараташвили Т.К. Эффрективные технологии в решении природоохранных, экологических, экономических, социальных и других проблем XXI века. Матер. II междунар. науч.-практ. конф. «ЭМтехнология и реальность». Улан-Удэ, 2013. С. 219-225.

8. Смірнов В.В. Мікробні біотехнології у сільському господарстві Вісник аграрної науки. 2002 . № 4. C. $5-10$.

9. Козировська Н., Деркач В. В Україні зареєстровано перший вітчизняний мікробіологічний препарат для рослинництва КЛЕПС. Пропозиція. 2001. № 10. С. 60-61.

10. Фокін А. Деякі світові тенденції у захисті рослин. Захист рослин. 2014. № 9. С. 13-15.

11. Сайко В.Ф. Наукові основи стійкого землеробства в Україні Вісник аграрної науки. 2014. № 1. С. 5-12.

12. Тихоновича И., Круглова Ю. Биопрепараты в сельском хозяйстве. Методология и практика применения микроорганизмов в растениеводстве и кормопроизводстве. Москва: ВНИИСХМ, 2014. 154 с.

13. Городній M.M. Біотехнологічний енергетично-автономний комплекс переробки і утилізації органічних відходів. Матеріали науково-практичної конореренції «Вищі навчальні заклади - Києву», 12 березня 2004 р. Київ, 2004. Ч. 1. С. 66-72.

14. Кузьменко А.С. Вплив мікробіологічних препаратів на врожайність суцвіть. Вісник аграрної науки УААН. 2004. № 3. С. 76-78.

15. Волкогон В.В. Мікробіологія в сучасному аграрному виробництві. Сільськогосподарська мікробіологія: Міжвід. темат.наук. зб. Чернігів, 2005. Вип. 1-2. С. 6-29.

\section{Інформація про авторів}

Василенко Ольга Володимирівна - кандидат сільськогосподарських наук, доцент, Уманський національний університет садівництва (Україна, 20305, м. Умань, вул. Інститутська, 1; е-mail: vsolga05@gmail.com)

Балабак Алла Василівна - кандидат сільськогосподарських наук, доцент, Уманський національний університет садівництва (Україна, 20305, м. Умань, вул. Інститутська, 1; e-mail: A.V.Balabak@ukr.net).

O.V. Vasylenko

$\mathrm{PhD}$, Associate Professor

Uman National University of Horticulture (Ukraine, Uman; e-mail: vsolga05@gmail.com)

A.V. Balabak

PhD, Associate Professor

Uman National University of Horticulture

(Ukraine, Uman; e-mail: A.V.Balabak@ukr.net)

\section{AGRI-ENVIRONMENTAL FUNDAMENTALS OF GROWING ENVIRONMENTALLY SAFE COMMERCIAL PRODUCTS OF MENTHA PIPERITA}

Three-year researches have been conducted to study the effect of microbiological products on the yield and quality of commercial products of peppermint. The subject of the study was phenological changes, biometric indicators and parameters of crop yields, depending on the application of such microbiological products as EM-A, Siaivo-2 and EM-plates. During the scientific work, field, statistical, laboratory research methods were used. Phenological observations, biometric measurements, accountings and biochemical analysis of plants were carried out. As a result of the research conducted, the consistent pattern of the formation of a high level of yield of the commercial products of peppermint, depending on the use of EMproducts, are substantiated. Thus, the fertilizing of peppermint plants during the growing season with a solution of the microbiological preparation EM-A stimulated the growth of leaf mass and improved the foliage of the plants. Accordingly, the yield of plants of this variant of the experiment was the largest $3.9 \mathrm{t} / \mathrm{ha}$. The results show that when exposed to microbiological products, regardless of their choice, the content of nitrates in the green mass of peppermint decreased compared with the control. In addition, our studies revealed a tendency to an increase in the content of essential oil in peppermint leaves under 
the influence of microbiological products. The positive effect of microbiological products on the growth, development and yield of this crop has been proved and it has been determined that the use of the microbiological preparation EM-A by fertilizing during the growing season can be included as an effective, environmentally safe element in modern technology of growing this culture.

Keywords: peppermint, microbiological products, EM-A, Siaivo-2, EM-plates, fertilizing, yield, nitrates, essential oil, commercial products.

\section{REFERENCES}

1. Dubynskyj, G.P. \& Burakov, V.Y. (2012). Pochvozashhytnoe ustrojstvo agrolandshafta [Agrolandscape soil protection device]. Xarkiv: Vyshha shkola. 216. (In Ukr.)

2. Palamarchuk, I.P., Palamarchuk, I.I. and Yanovych, V. P. (2013). Технологічні аспекти використання есрективних мікроорганізмів у відновлюючи процесах [Technological aspects of the use of effective microorganisms in restoring processes]. Zbirnyk Naukovykh Prats Vinnytskoho Natsionalnoho Ahrarnoho Universytetu [Collection of scientific works of Vinnytsia National Agrarian University], 10, Vols. 1 (58), 164-167. (In Ukr.)

3. Gutynska, G.O. (2006). Gruntova mikrobiologiya [Soil microbiology]. Kyiv: Aristej. 284. (In Ukr.)

4. Tyburskyj, I.Yu. (2006). Ekologichne silske gospodarstvo: kroky nazustrich. Krok pershyj: ekologichne zemlerobstvo [Ecological agriculture: steps towards. Step one: ecological agriculture]. Kyiv: Vydavnycztvo Nacionalnogo agrarnogo universtetu. 80. (In Ukr.)

5. Stecyshyn, P.O., Pyndus, V.V., Rekunenko, V.V. et all. (2011). Osnovy organichnogo vyrobnycztva [Fundamentals of organic production]. Vinnycya: Nova knyga. 626. (In Ukr.)

6. Zelinskyj, M. (2015). Organichne zemlerobstvo - ce shans ne vyzhyvaty, a zhyty i rozvyvatys [Organic farming is a chance not to survive, but to live and develop]. Agrosvit Ukrayiny [Agrosvit of Ukraine], 1. 8-10. (In Ukr.)

7. Baratashvili, T.K. (2013). "Effektivnye tehnologii v reshenii prirodoohrannyh, ekologicheskih, ekonomicheskih, socialnyh $i$ drugih problem XXI veka». Zbirnyk materialiv I mezhdunarodnoj nauchnoj konferencii [EM technology and reality], I Mezhdunarodnaya nauchnaya konferenciya, Ulan-Ude, Russia, pp. 219-225. (In Russ.)

8. Smirnov, V.V. (2002). Mikrobni biotekhnolohii u silskomu hospodarstvi [Microbial biotechnology in agriculture]. Visnyk ahrarnoi nauky [Bulletin of agrarian science.], 4. 5-10. (In Ukr.)

9. Kozyrovska, N. \& Derkach, V. (2001). V Ukraini zareiestrovano pershyi vitchyznianyi mikrobiolohichnyi preparat dlia roslynnytstva KLEPS [In Ukraine the first domestic microbiological preparation for the CLEPS crop was registered]. Propozytsiia [Proposal], 10. 60-61. (In Ukr.)

10. Fokin, A. (2014). Deiaki svitovi tendentsii u zakhysti roslyn. [Some world trends in plant protection]. Zakhyst Roslyn [Plant Protection.], 9. 13-15. (In Ukr.)

11. Saiko, V.F. (2014). Naukovi Osnovy Stiikoho Zemlerobstva V Ukraini Visnyk Ahrarnoi Nauky [Scientific fundamentals of sustainable agriculture in Ukraine]. Visnyk agrarnoyi nauky [Bulletin of agrarian science], 1, 5-12. (In Ukr.)

12. Tihonovicha, I. \& Kruglova, Yu. (2014). Biopreparaty $v$ selskom hozyajstve. Metodologiya $i$ praktika primeneniya mikroorganizmov $v$ rastenievodstve $i$ kormoproizvodstve. [Biological products in agriculture. Methodology and practice of using microorganisms in crop production and feed production]. Moscow: VNIISHM. 154. (In Russ.)

13. Horodnii, M.M. (2004). "Biotekhnolohichnyi enerhetychno-avtonomnyi kompleks pererobky $i$ utylizatsii orhanichnykh vidkhodiv". Zbirnyk materialiv naukovo-praktychnoi konferentsii [Vyshchi Navchalni Zaklady - Kyievu], Naukovo-praktychna konferentsiia, Kyiv, Ukraine, pp. 66-72. (In Ukr.)

14. Kuzmenko, A.S. (2004). Vplyv mikrobiolohichnykh preparativ na vrozhainist sutsvit. [Influence of microbiological preparations on the yield of inflorescences]. Visnyk Ahrarnoi Nauky UAAN [Bulletin of agrarian science of UAAS], 3. 76-78. (In Ukr.)

15. Volkohon, V.V. (2005). Mikrobiolohiia v suchasnomu ahrarnomu vyrobnytstvi. [Microbiology in modern agrarian production]. Silskohospodarska mikrobiolohiia [Agricultural Microbiology], 1-2. 6-29. (In Ukr.)

\section{Authors}

Vasylenko Olha Volodymyrivna - PhD, Associate Professor, Uman National University of Horticulture (Ukraine, 20305, Uman, 1 Institutska Str; e-mail: vsolga05@gmail.com)

Balabak Alla Vasylivna — PhD, Associate Professor, Uman National University of Horticulture (Ukraine, 20305, Uman, 1 Institutska Str; e-mail: A.V.Balabak@ukr.net) 